\title{
Limiting the Use of Acquitted and Uncharged Conduct at Sentencing: Apprendi v. New Jersey and Its Effect on the Relevant Conduct Provision of the United States Sentencing Guidelines
}

\author{
Freya Russell $\dagger$
}

Since the adoption of the United States Sentencing Guidelines, sentencing courts have been permitted to consider all "relevant conduct" (including acquitted and uncharged conduct) when determining the guidelines range for an offense, provided the underlying facts were proven to the judge by a preponderance of the evidence. However, in June 2000, the Supreme Court held in Apprendi v. New Jersey that facts which support an increase in the maximum sentence for an offense must be charged in an indictnient and proven to a jury beyond a reasonable doubt. The Court did not specifically address the ruling's effect on the United States Sentencing Guidelines. This Casenote argues that after Apprendi, sentencing courts may no longer use the Relevant Conduct Provision of the federal sentencing guidelines to increase the guidelines range for an offense based on acquitted or uncharged conduct.

\section{INTRODUCTION}

Cheryl Putra was a small-time drug dealer who was not in the business of distributing large quantities of cocaine. At least this is what a jury

Copyright (c) 2001 Califomia Law Review, Inc. Califomia Law Review, Inc. (CLR) is a Califomia nonprofit corporation. CLR and the authors are solely responsible for the content of their publications.

- $\quad$ J.D. Candidate, School of Law, University of Califomia, Berkeley (Boalt Hall), 2002; Ph.D., University of California, Berkeley (English), 1999; M.A., San Diego State University (English), 1992; B.A., San Diego State University, 1991. I wish to thank Professors Daniel Abrahamson and Ayelet Waldman for their guidance in overseeing the beginning of this Casenote in their inspirational "War on Drugs" seminar, and Professor Kathleen Vanden Heuvel for her advice and support in overseeing its completion. I am grateful to California Law Review members Kate Barry, Ben Beltramo, Jesse Ladomirak, Jerrod Patterson, Benjamin Shreck, Jason Snyder and Carla Veltman for their careful editing of this manuscript. 
of her peers decided after hearing the evidence against her at trial. They convicted her of aiding and abetting the possession and distribution of one ounce of cocaine, but acquitted her on a charge of aiding and abetting distribution of five ounces of cocaine. ${ }^{1}$ The sentencing court, however, had a different opinion. It determined by a preponderance of the evidence that Cheryl Putra had aided in the distribution of the five ounces of cocaine, and applied the appropriate sentence. ${ }^{2}$ Under the United States Sentencing Guidelines, her term of imprisonment for possessing one ounce of cocaine would have been fifteen to twenty-one months. ${ }^{3}$ Five ounces would merit a term of imprisonment of twenty-seven to thirty-three months. ${ }^{4}$ Accordingly, the court sentenced Cheryl Putra to twenty-seven months in prison. ${ }^{5}$

The sentencing court was able to ignore the jury's acquittal because the Relevant Conduct Provision of the United States Sentencing Guidelines requires a sentencing court, when determining the guidelines range for an offense, to consider "all acts and omissions ... that were part of the same course of conduct or common schenie or plan as the offense of conviction." The commentary to the provision expressly provides that relevant conduct includes "conduct that is not formally charged or is not an element of the offense of conviction." In addition, the commentary notes that the defendant need not have been convicted on multiple counts in order for multiple offenses to be considered when determining the offense level. ${ }^{8}$ The Supreme Court has held that in applying this provision,

1. United States v. Putra, 78 F.3d 1386, 1387 (9th Cir. 1996), rev'd per curiam sub nom. United States v. Watts, 519 U.S. 148 (1997).

2. Id.

3. Id.

4. Id. See also U.S. Sentencing Guidelines Manual § 2D1.1(c) (2000).

5. Putra, 78 F.3d at 1387. The Ninth Circuit Court of Appeals vacated Putra's sentence, holding that the Relevant Conduct Provision of the sentencing guidelines may not authorize "a court to reconsider facts during sentencing that have been rejected by the jury's not guilty verdict." Id. At 1389 (citing United States v. Brady, 928 F.2d 844, 851 (9th Cir. 1991)). To allow a sentence based on acquitted conduct, the court concluded, "would make the jury's findings of fact pointless." Id. The Supreme Court reversed, explaining that "acquittal on criminal charges does not prove the defendant is innocent; it merely proves the existence of a reasonable doubt as to his guilt." United States v. Watts, 519 U.S. 148, 155 (1997) (per curiam). Rather than a finding of fact, an acquittal is merely an acknowledgment that the government failed to prove an essential element of the offense beyond a reasonable doubt. $I d$. Therefore, the Court concluded, an acquittal does not prevent the government from relitigating an issue when it is presented in a proceeding governed by a lower standard of proof. Id. at 156. Because the preponderance of the evidence standard satisfies due process at sentencing, the Court concluded that a jury's verdict of acquittal does not prevent a sentencing court from considering conduct underlying the acquitted charge provided it is proven by a preponderance of the evidence. Id. at 157.

6. U.S. Sentencing Guidelines Manual $\S 1 \mathrm{~B} 1.3(\mathrm{a})$ (2000). This section is entitled "Relevant Conduct (Factors that Determine the Guideline Range)."

7. U.S. SENTENCING GuIDELINES MANUAL $§ 1 B 1.3$, cmt. background (2000).

8. U.S. Sentencing Guidelines Manual $\S 1 \mathrm{~B} 1.3$, cmt. n.3 (2000). The commentary explains, "[f]or example, where the defendant engaged in three drug sales of 10,15 , and 20 grams of cocaine, as part of the same course of conduct or common scheme or plan, subsection (a)(2) provides 
sentencing courts inay consider conduct for which the defendant has been acquitted, ${ }^{9}$ conduct for which the defendant can still be tried and sentenced in a separate criminal proceeding, ${ }^{10}$ and uncharged conduct. ${ }^{11}$ However, in June 2000, the Supreme Court's ruling in Apprendi v. New Jersey cast doubt on the constitutionality of sentences like Cheryl Putra's. In Apprendi, the Court held that "any fact (other than prior conviction) that increases the maximum sentence for a crime inust be charged in an indictment, submitted to a jury, and proven beyond a reasonable doubt."12 The Court did not address whether, and if so, how, this holding affects the current application of the United States Sentencing Guidelines. ${ }^{13}$ This Note examines the Court's reasoning and its treatment of precedent, and argues that Apprendi precludes the sentencing judge from using acquitted or uncharged conduct to expand the guidelines range, thus restricting the application of the Relevant Conduct Provision of the United States Sentencing Guidelines. $^{14}$

that the total quantity of cocaine involved (45 grams) is to be used to determine the offense level even if the defendant is convicted of a single count charging only one of the sales."

9. United States v. Watts, 519 U.S. 148, 157 (1997) (per curiam), held that a jury's verdict of acquittal does not prevent the sentencing court from considering conduct of the accused which underlay the acquitted charge. See supra note 5.

10. Witte v. United States, 515 U.S. 389, 405 (1995), held that the Double Jeopardy Clause was not violated by prosecuting the accused on federal cocaine charges, even though the conduct giving rise to those charges had previously been considered in determining the defendant's sentence for a federal marijuana offense.

11. Id. at 402 .

12. 530 U.S. $466,476(2000)$. This Note will argue that Apprendi would invalidate the use of the Relevant Conduct Provision as it was used in Watts (Cheryl Putra's case on appeal). However, the holding in the case itself should remain good law, just more limited in its application. See infra note 187 and accompanying text.

13. Apprendi, 530 U.S. at 497 n.21 ("The Guidelines are, of course, not before the Court. We therefore express no view on the subject beyond what this court has already held.").

14. The United States Sentencing Guidelines were adopted pursuant to The Sentencing Reform Act of 1984 (Title II of the Comprehensive Crime Control Act of 1984). U.S. SENTENCING GuIDELINES MANuAL ch. 1, pt. A, introductory cmt. 2. (2000). They were promulgated to limit what was considered excessive judicial discretion in imposing sentence, which led to a wide disparity in sentences imposed for similar crimes under the indeterminate sentencing scheme previously utilized in federal courts. See U.S. Sentencing Gumelines Manual ch. 1, pt. A, introductory cmt. 3. (2000). The act provides for the establishment of The United States Sentencing Commission, an independent agency in the judicial branch whose principal purpose is to establish sentencing policies and practices for the federal criminal justice system. U.S. Sentencing Guidelines Manual ch. 1, pt. A, introductory cmt. l. (2000). The act directs the commission to create categories of offense behavior and offender characteristics. The commission is then required to prescribe guidelines ranges that specify an appropriate sentence for each class of convicted persons determined by the combination of their offense behavior categories and their offender characteristics categories. U.S. SENTENCING Gumelines MANUAL ch. 1, pt. A, introductory cmt. 2. (2000). For example, trespass carries a base offense level of four. U.S. SENTENCING Guidelines Manual $\$ 2 B 2.3$.(a) (2000). To determine the guidelines range for this offense, one would consult the sentencing table at the back of the manual. For an offense level of four, the guidelines range for a person in Criminal History Category I (one or two Criminal History Points) would be zero to six months in prison. The same range applies for categories II and III. For an offender in category IV (seven to nine Criminal History Points), the guidelines range would be two to eight months. Categories V and VI carry guidelines ranges of four to ten, and six to twelve months, 
Part I sets out the factual background and lower court decisions in Apprendi. Part II examines the relevant Supreme Court jurisprudence leading up to the decision. Part III analyzes the language and reasoning of the decision and the majority's use of precedent, concluding that an increase in the guidelines range is an increase in the maximum sentence for the purpose of the Court's holding. Part IV discusses how the decision can be reconciled with deference to the legislature and how the rule should be applied at sentencing.

\section{I}

\section{APPRENDI V. NEW JERSEY}

\section{A. Factual Background}

On December 22, 1994, defendant Charles Apprendi fired several twenty-two-caliber bullets into the home of an African-American family that had recently moved into his previously all-white neighborhood in Vineland, New Jersey. ${ }^{15}$ Upon arrest he admitted that he was the shooter. ${ }^{16}$ A New Jersey grand jury issued a twenty-three count indictment, charging Apprendi with shootings on four different dates, in addition to unlawful possession of assorted weapons. ${ }^{17}$ None of the counts alleged that Apprendi acted with racially biased purpose. ${ }^{18}$

respectively. See U.S. Sentencing Guidelines Manual sentencing tbl. (2000). However, the trespass sentencing guideline specifies that if the trespass occurred at a secured government facility, a nuclear energy facility, or a residence, then the offense is increased by two levels. U.S. SENTENCING GUIDELINES MANUAL $§ 2 B 2.3$.(b) (2000). Thus the offense level would be six, rather than four, and the applieable guidelines ranges would be zero to six, one to seven, two to eight, six to twelve, nine to fifteen, or twelve to eighteen months depending on the Criminal History Category. See U.S. Sentencing Guidelines Manual sentencing tbl. (2000). Imagine a defendant in Criminal History Category III is tried for trespass and convicted by a jury. The indictment did not charge that trespass occurred at a residencc, and the jury did not hear and consider evidence concerning whether the defendant trespassed at a residence. Under the current application of the Relevant Conduct Provision, the sentencing judge could then hear evidence concerning whether the defendant committed the trespass at a residence and determine by a preponderance of the evidence that the defendant did so. Accordingly, the defendant's guidelines range would increase from the zero to six months range that accompanied the offense of conviction to the two to eight months range permitted for a level six offense. U.S. SENTENCING Guidelines MANUAL § IB1.3(a) (2000). The same result could not obtain if the jury had acquitted the defendant of trespassing near a residence and had instead just convicted him or her of simple trespass. See id.; see also United States v. Watts, 519 U.S. 148 (1997) (per curiam).

15. Apprendi, 530 U.S. at 469.

16. Id. After further questioning he stated that he did not know the occupants of the house personally, but "because they are black in color he does not want them in the neighborhood." He said that he was "just giving them a message that they were in his neighborhood." State v. Apprendi, 731 A.2d 485, 486 (N.J. 1999), rev'd, 530 U.S. 466 (2000). He later retracted the statement. Apprendi, 530 U.S. at 469 .

17. The indictment charged Apprendi with four first-degree, eight second-degree, six thirddegree, and five fourth-degree offenses. Apprendi, 530 U.S. at 469.

18. Id. 
Pursuant to a plea agreement, Apprendi pled guilty to two counts of second-degree possession of a firearm for an unlawful purpose and one count of third-degree unlawful possession of an antipersonnel bomb. ${ }^{19}$ The prosecutor dismissed the other twenty counts. However, the state reserved the right to request a higher "enhanced" sentence for the count of seconddegree possession of a firearm for an unlawful purpose that was based on the December 22 shooting. The prosecutor reserved this right on the ground that this offense was committed with a biased purpose, as described in New Jersey's "hate crime" sentencing-enhancement statute. ${ }^{20}$ The statute provides for "an 'extended term' of imprisonment if the trial judge finds by a preponderance of the evidence, that ' $[t]$ he defendant in committing the crime acted with the purpose to intimidate an individual or group of individuals because of race, color, gender, handicap, religion, sexual orientation or ethnicity." "'21 Under New Jersey law, the penalty range for a second-degree offense is imprisonment for five to ten years, ${ }^{22}$ a thirddegree offense carries a penalty range of three to five years. ${ }^{23}$ However, the extended term authorized for second-degree offenses under the hate crime statute is imprisonment for ten to twenty years. ${ }^{24}$ Because the plea agreement stipulated that the sentence on the third-degree count would run concurrently with the other sentences, the longest prison term that Apprendi could receive absent a finding of racial bias would be twenty years, the maximum consecutive sentence for the second-degree counts. ${ }^{25}$ Application of the biased-purpose enhancement would increase the maximum sentence on the "enhanced" count alone to twenty years, thus exposing Apprendi to an aggregate maximum of thirty years. ${ }^{26}$

Following an evidentiary hearing, the trial judge found by a preponderance of the evidence that Apprendi's actions in the December 22 shooting were taken "with a purpose to intimidate," as provided by the hate crime statute, and applied the sentence enhancement. ${ }^{27}$ Apprendi was sentenced to a twelve-year prison term for the firearm possession count connected to that shooting, with two shorter sentences on the other counts to run concurrently. ${ }^{28} \mathrm{He}$ appealed his conviction, alleging that the sentence

\footnotetext{
19. Id. at 469-70.

20. Id. at 470 .

21. Id, at 468-69 (citing N.J. Stat. ANN. \$ 2C:44-3(e) (West. Supp. 2000)).

22. Id. at 470 (citing N.J. StAT. ANN. \& 2C:43-6(a)(2) (West 1995)).

23. Id. (citing N.J. Stat. ANN. \& 2C:43-6(a)(3) (West 1995)).

24. Id. at 469 (citing N.J. Stat. ANN. § 2C:43-7(a)(3) (West. Supp. 2000)).

25. See id. at 470 .

26. Id.

27. Id. at 470-71.

28. Id. at 471. The state argued to the Supreme Court that because the trial court could have imposed consecutive rather than concurrent sentences, Apprendi's twelve-year sentence was therefore within the range authorized by statute for the three offenses for which he had pled guilty. The Court responded that
} 
enhancement based on the factual finding of bias was an unconstitutional due process violation because his motive for the shooting had not been proven to a jury beyond a reasonable doubt. ${ }^{29}$

\section{B. The Lower Appellate Court Decisions}

The Appellate Division of the Superior Court of New Jersey rejected Apprendi's due process claiun. Relying on McMillan $v$. Pennsylvania ${ }^{30}$ the court determined that the hate crime statute at issue in Apprendi operated as a "sentencing factor" and thus was not subject to the reasonable doubt standard. ${ }^{31}$ Although recognizing that the hate crime enhancement exposes the defendant to "greater and additional punishment," the court concluded that this factor standing alone did not render the statute unconstitutional. ${ }^{32}$

The New Jersey Supreme Court affirmed the decision. Agreeing with the appellate court's analysis that the hate crime provision was a "sentencing factor" rather than an eleinent of the crime, the court pronounced the statute valid because it did not allow impermissible burden-shifting or create a "separate offense calling for a separate penalty." cluded that the statute's alteration of the maximum penalty for the crime did not "change the constitutional calculus." 34

[t]he constitutional question, however, is whether the twelve-year sentence imposed on [the count based on the December 22 shooting] was permissible, given that it was above the 10 year maximum for the offense charged in the count. The finding is legally significant because it increased-indeed, it doubled-the maximum range within which the judge could exercise his discretion, converting what otherwise was a maximum 10-year sentence on that count into a minimum sentence. The sentences on [the other two counts] have no more relevance to our disposition than the dismissal of the remaining 18 counts.

Id. at 474 .

29. Id. at 471 .

30. 477 U.S. 79 (1986). See infra notes 80-87 and accompanying text.

31. State v. Apprendi, 698 A.2d 1265, 1268 (N.J. Super. App. Div. 1997), affd, 731 A.2d 485 (N.J. 1999), rev'd, 530 U.S. 466 (2000) (citing McMillan v. Pennsylvania, 477 U.S. 79, 91 (1986)). The court explained:

The Hate Crime Statute acts as a sentencing factor. The language in the statute is not included in the definition of any crime in the New Jersey Code of Criminal Justice. Instead, the statute is included in the section of the code entitled 'authority of court in sentencing.' As to sentencing factors which are not elements of a crime, the State's burden of proof is not subject to the reasonable doubt standard.

Id.

32. Id. at 1269 (quoting McMillan v. Pennsylvania, 477 U.S. 79, 88 (1986)). The Supreme Court upheld the constitutionality of a sentencing provision that raised the mandatory minimum sentence based on a finding that the accused had possessed a firearm, specifically noting that the enhancement did not expose the defendant to "greater and additional punishment." McMillan v. Pennsylvania, 477 U.S. 79, 88 (1986). The appellate court addressed the apparent contradiction with the holding in McMillan, conceding that because the hate crime statute does expose the defendant to greater and additional punishment, his claim that it is unconstitutional has "superficial appeal." However, the court opined, "this one factor standing alone does not place the statute on the impermissible side of the constitutional line." Apprendi, 698 A.2d at 1269.

33. State v. Apprendi, 731 A.2d 485, 494 (N.J. 1999), rev'd, 530 U.S. 466 (2000).

34. Id. at 495. The court acknowledged that in Jones v. United States the Supreme Court had just the previous year expressed doubts about the permissibility of allowing penalty-enhancing findings to 


\section{The Supreme Court Decision}

\section{The Majority Opinion}

The United States Supreme Court granted certiorari and reversed the decision. ${ }^{35}$ Justice Stevens, writing for the majority, announced the rule that "under the Due Process Clause of the Fifth Amendment and the notice and jury trial guarantees of the Sixth Amendment, any fact (other than prior conviction) that increases the maximum penalty for a crime must be charged in an indictment, submitted to a jury, and proven beyond a reasonable doubt." ${ }^{36}$ The Court declared that " $[t]$ he Fourteenth Amendment commands the same answer in this case involving a state statute."37 The majority opinion was jomed by Justices Scalia, Thomas, Ginsburg and Souter.

The Court explained that, taken together, the Fourteenth Amendment's protection against deprivation of liberty without due process of law and the Sixth Amendment's guarantee of a speedy and public trial by an impartial jury "indisputably entitle a criminal defendant to a 'jury determination that he is guilty of every element of the crime with which he is charged, beyond a reasonable doubt.""38 Reviewing the "historical foundation" for this principle, the Court contended that a centuries-long common law tradition mandates two "companion rights": the truth of every accusation must always be confirmed by a unamimous jury, and this verdict nuust be based on proof beyond a reasonable doubt. ${ }^{39}$ The Court identified a historic link between verdict and punishment and the consistent confinenient of judges' discretion within the prescribed statutory range. ${ }^{40}$ They concluded that historically, "facts that expose a defendant to a punishment greater than that otherwise legally prescribed were by definition 'elements' of a separate legal offense."41

The Court declared that the New Jersey statute could not stand in light of the constitutional rule it had announced. The majority noted that the

be determined by a judge by a preponderance of the evidence. See id. at 493 . However, the court opined that Jones was decided as "a matter of statutory construction, not constitutional requirement." Id. (citing Jones v. United States, 526 U.S. 227, 243 n.6 (1999)). See infra Part II.C for a discussion of Jones.

35. Apprendi v. New Jersey, 530 U.S. 466 (2000). The Court noted that although Apprendi's twelve-year sentence was within the range the court could have imposed without the finding of bias, the constitutional question was limited to the sentence imposed for the December 22 shooting. Because the maximum sentence for that offense was ten years, and the sentence imposed exceeded that ainount, it presented a constitutional issue. Id. at 474.

36. Id. at 476 (citing Jones v. United States, 526 U.S. 227, 243 n.6 (1999)). The Court noted that the Apprendi ruling "was foreshadowed by our opimion in Jones $v$. United States construing a federal statute." Id.

37. Id.

38. Id. at 477 (quoting United States v. Gaudin, 515 U.S. 506, 510 (1995)).

39. Id. at $477-78$.

40. Id. at $478-79$.

41. Id. at 483 n.10. 
"motive" sentencing factor in the New Jersey statute was functionally akin to mens rea and as such seemed more like a traditional element. ${ }^{42}$ But the Court made clear that this was not the dispositive issue: "[t]he relevant inquiry is not one of form, but of effect-does the required finding expose the defendant to a greater punishment than that authorized by the jury's guilty verdict?"43 The Court pointed out that the New Jersey statutory scheme required a jury to convict a defendant of a second-degree offense based on a finding of fact beyond a reasonable doubt, but then permitted a judge to impose a penalty identical to one for a first-degree offense based upon a finding of fact by a preponderance of the evidence. ${ }^{44}$ Because this is "an unacceptable departure from the jury tradition that is an indispensable part of our criminal justice system," ${ }^{, 45}$ the Court concluded that the New Jersey statute was unconstitutional.

\section{The Concurrences}

Justice Scalia filed a short concurrence responding to the dissenting opinions and what he characterized as Justice Breyer's "bureaucratic realm of perfect equity" in which the facts relevant to the length of a defendant's sentence are to "be determined to exist (on a more-likely-than-not basis) by a single employee of the State. ${ }^{.46}$ The Sixth Amendment's guarantee of a jury trial, he maintained, "has no intelligible content unless it means that all the facts which must exist in order to subject the defendant to a legally prescribed punishment must be found by the jury."

Justice Thomas filed a concurring opimion which Justice Scalia joined in part. While joining the majority's opinion in full, he argued that the Constitution requires a broader rule than the one adopted by the Court; ${ }^{48}$ recidivism should not be exempted from the rule requiring jury determination of facts relevant to sentencing. ${ }^{49}$ Historical precedent, Thomas argued,

42. Id. at 492. The Court noted its disapproval of the proposition that the "purpose to intimidate" language of the statute was merely inquiry into "motive," and as such was somehow not an element of the crime. It explained,

this statute mandates an examination of the defendant's state of mind-a concept known well to the criminal law as ... mens rea. ... [I]t is precisely a particular criminal mens rea that the hate crime enhancement statute seeks to target. The defendant's intent in committing a crime is perhaps as close as one might hope to come to a core criminal offense "element."

Id. at $492-93$.

43. Id. at 494

44. Id. at 491 .

45. Id. at 497 .

46. Id. at 498 (Scalia, J., concurring).

47. Id. at 499. He added, "Justice Breyer proceeds on the erroneous and all-too-common assumption that the Constitution means what we think it ought to mean. It does not; it means what it says."

48. Id. (Thomas, J., concurring).

49. Id. at 502. He has apparently changed his mind since joining the majority opinion in Almendarez-Torres $v$. United States, 523 U.S. 224 (1998), which held that recidivism does not need to be found by a jury beyond a reasonable doubt. 
establishes that "a 'crime' includes every fact that is by law a basis for imposing or increasing punishment."

\section{The Dissenting Opinions}

Declaring that the case will be remembered as a "watershed change in constitutional law," the dissent criticized Apprendi for "the serious doubt that the holding cast[s] on sentencing systems employed by the Federal Government and States alike."5l Justice O'Connor, joined by Justices Rehnquist, Kennedy, and Breyer, disputed the majority's analysis of precedent, contending that the Court has long recognized that not every fact bearing on a defendant's punishment need be charged in an indictment or proven to a jury beyond a reasonable doubt. ${ }^{52}$ Rather, the Court usually gives deference to the legislature's definition of the elements of an offense..$^{53} \mathrm{O}$ 'Connor further noted that although there are some constitutional limits to the legislature's discretion in this regard, the Court has declined to establish a bright-line rule. Instead, the Court has approached each case individually, "sifting through the considerations most relevant to determining whether the legislature has acted properly within its broad power to define crimes and their punishments." ${ }^{34}$ Apprendi, according to O'Connor, is an unfortunate departure from this deliberative tradition..$^{55}$ In her view, by establishing a clear constitutional rule requiring juries alone to determine facts that increase a prescribed range of penalties, the majority implicitly overruled its prior line of cases supporting legislative determination of sentencing factors. ${ }^{56}$ This, she warned, will have "severe consequences" for the determinate-sentencing schemes adopted by many States and the Federal Government. ${ }^{57}$ This sentiment was shared and reiterated by Justice Breyer in his separate dissent. ${ }^{58}$

50. Id. at 501 .

51. Id. at 524 (O'Connor, J., dissenting).

52. Id.

53. Id.

54. Id.

55. See id. She adds, "[i]n one bold stroke the Court today casts aside our traditional cautious approach and instead embraces a universal and seemingly bright-line rule limiting the power of Congress and state legislatures to define criminal offenses and the sentences that follow from convictions thereunder." Id. at 525.

56. See id. at 543-44.

57. Id. at 544 .

58. Justice Breyer, joined by Justice Rehnquist, wrote separately to detail the importance of judicial factfinding at sentencing, and to express his concern about the "disruption" the Court's raling would have on determinate-sentencing schemes such as that codified in the United States Sentencing Guidelines. Id. at 555-66 (Breyer, J., dissenting). The criminal justice system, he argued, ean only function with the aid of "procedural compromises" which preclude implementation of the procedural model suggested by the majority opinion. Id. at 555 . He contended there are far too many factors relevant to sentencing to permit, as a practical matter, submission of all or even most of them to a jury. Id. at 556-57. 
II

\section{LEGAL BACKGROUND}

Apprendi drew on two lines of Supreme Court cases that grapple with the issues of what must be proven in order to sentence a defendant, when and by whom it must be proven, and what standard of proof should govern the proceeding. The first line of cases considers what standard of proof should govern at trial and what the state must prove. The second line of cases distinguishes sentencing proceedings from trial for the purposes of due process protection. Jones $v$. United States, decided just one year prior to Apprendi, built upon both lines of cases and announced the "constitutional principle" which became the holding in Apprendi. ${ }^{59}$

\section{A. Constitutional Protections at Trial}

In re Winship ${ }^{60}$ established that the reasonable doubt standard is a constitutional requirement for all criminal trials. The Court explicitly linked the rigorous standard to the necessity of "reducing the risk of convictions resting on factual error." Process Clause protects the accused against conviction except upon proof beyond a reasonable doubt of every fact necessary to constitute the crime with which he is chargcd." $" 62$

Five years after Winship, Mullaney $v$. Wilbur ${ }^{63}$ considered the constitutionality of a murder statute requiring a murder defendant to prove he acted in the heat of passion to reduce the homicide to manslaughter. Relying on Winship, the Court invalidated the statute, declaring that due process requires the prosecution to bear the burden of proving beyond a reasonable doubt the absence of provocation when the issue arises in a homicide case.$^{64}$ In determining the absence of provocation to be a "fact necessary to constitute a crime" as defined by Winship, the Court noted that if Winship were limited to only those facts which constitute a crime as defined by state law, a state "could underminc many of the interests that decision sought to protect without effecting any substantive change in its law." The Court explicitly rejected the state's argument that the statute did not

59. See Jones v. United States, 526 U.S. 227,243 n.6 (1999).

60. 397 U.S. 358,364 (1970).

61. Id. at 363 .

62. Id. at 364. The Court rejected the preponderance of the evidence standard, noting that it is "susceptible to the misinterpretation that it calls on the trier of fact merely to perform an abstract weighing of the evidence in order to determine which side has produced the greater quantum, without regard to its effect in convincing his mind of the truth of the proposition asserted." Id. at 367-68.

63. 421 U.S. 684 (1975). The murder statute carried a mandatory sentence of life imprisonment whereas manslaughter carried a statutory maximum of twenty years. Id. at 691-92.

64. Id. at 704 .

65. Id. at 697 . The Court added that to undermine these interests, "it would only be necessary to redefine the elements that constitute different crimes, characterizing them as factors that bear solely on the extent of punishment," a prophetic observation in light of the Patterson decision two years later. 
implicate the defendant's liberty interests since he would lose his liberty if convicted of either variety of homicide, regardless of the presence or absence of provocation. ${ }^{66}$ The Court opined that the criminal law "is concerned not ouly with guilt or innocence in the abstract but also with the degree of criminal culpability." ${ }^{\circ 7}$

Just two years after Mullaney, Patterson v. New York ${ }^{68}$ upheld a state murder statute which required the defendant to prove by a preponderance of the evidence the affirmative defense of extreme emotional distress to reduce the crime from murder to manslaughter. ${ }^{69}$ The Court justified this seemingly contradictory ruling by distinguishing the statute im Patterson from the one in Mullaney. The Patterson Court explained that malice was defined as the absence of provocation and was included as an element of the offense. ${ }^{70}$ Rather than requiring the prosecution to prove this eleinent beyond a reasonable doubt, the statute required the defendant to negate the element by proving the presence of provocation. ${ }^{71}$ The statute therefore violated due process. In this sense, according to the Court, Mullaney only required that the reasonable doubt standard be applied to elements of the offense charged. In contrast, the Court determined that the Patterson statute did not presume anything against the defendant. Lack of provocation was not an element of the offense; the defendant did not have to prove the presence of provocation, but rather was permitted to show provocation as an affirmative defense after the state had proven the elements of the offense beyond a reasonable doubt. ${ }^{72}$

Justice Brennan, who wrote for the majority in Mullaney, dissented in Patterson. He accused the majority of differentiating the two statutes "on the basis of distinctions in language that are formalistic rather than substantive." ${ }^{973}$ The placement of the burden of persuasion affects the defendant exactly the same in both statutes, he argued. The majority's explanation of the Mullaney holding, he lamented, "bears little resemblance to the basic rationale of the decision." $" 74$

Thus after Patterson the state of due process protection at trial is ambiguous. Winship's requirement of proof beyond a reasonable doubt for facts constituting the crime remains in place; the definition of these crucial facts, however, is limited to the "eleinents" of the crime as defined by the

66. Id. at 697 .

67. Id. at 697-98. In light of the potential difference in restrictions on the defendant's personal liberty, the Court concluded that "the distinction between murder and manslaughter may be of greater importance than the difference between guilt or innocence for many lesser crimes." Id. at 698 .

68. 432 U.S. 197 (1977).

69. Id. at 206 .

70. Id. at 215-16.

71. Id. at 216.

72. Id. at 215-16.

73. Id. at 221 (Brennan, J., dissenting).

74. Id. at 223 . 
applicable statute. ${ }^{75}$ The Patterson Court acknowledged that not requiring the reasonable doubt standard when an identified fact increases the severity of punishment "may seem to permit state legislatures to reallocate burdens of proof by labeling as affirmative defenses at least some elements of the crimes now defined in their statutes."76 Although the Court asserted that "there are obviously constitutional limits beyond which the States may not go in this regard," the Court did not delineate those boundaries. ${ }^{77}$

\section{B. Constitutional Protections at Sentencing}

The Supreme Court also struggled with due process protection in distinguishing trial proceedings from sentencing. In Williams v. New York, the Supreme Court established that judges imposing sentence may consider evidence inadmissible at trial without violating due process. ${ }^{78}$ The Court held that a sentencing court may consider any information relevant to a defendant's character and conduct, concluding that "[h]ighly relevant-if not essential-to [a judge's] selection of an appropriate sentence is the possession of the fullest information possible concerning the defendant's life and characteristics."79

McMillan v. Pennsylvania, ${ }^{80}$ another watershed decision, held that due process is satisfied by the application of the preponderance of the evidence standard at sentencing. At issue was a state statute that sentenced defendants convicted of certain felonies to a mandatory minimum of five years iimprisonment if the state proved by a preponderance of the evidence that the defendant visibly possessed a firearm during the offense. ${ }^{81}$ The Court explicitly stated that the case was controlled by Patterson rather than Mullaney. ${ }^{82}$ Thus, due process only required proof beyond a reasonable doubt for the "elements" of the offense. Because the visible possession of a

75. Id. at 210 .

76. Id.

77. Id. The Court remarked that "[i]t is not within the province of a legislature to declare an individual guilty or presumptively guilty of a crime." Id. (citing McFarland v. American Sugar Ref. Co., 241 U.S. 79, 86 (1916)). Further, the legislature cannot "validly command that the finding of an indictment, or mere proof of the identity of the accused, should create a presumption of the existence of all the facts essential to guilt." Id. (citing Tot v. United States, 319 U.S. 463, 469 (1943)). However, the Court did not elaborate on how these "limits" play out with regard to the redefinition of elements of a crime.

78. 337 U.S. 241 (1949). The defendant was found guilty of first-degree murder, and the jury recommended life imprisonment. The trial judge imposed the death sentence, citing the pre-sentence investigation which revealed the "material fact" that the defendant had been involved in thirty other burglaries for which he had not been convicted, and referencing the defendant's "morbid sexuality" which had been evidenced by the probation report. Id. at 244 . The defendant had not been afforded the opportunity to confront or cross-examine the witnesses who supplied this information to the judge. Id. at 243.

79. Id. at 247.

80. 477 U.S. 79 (1986).

81. Id. at 85 .

82. Id. at 84 . 
firearm was not an enumerated element of the crime, it was instead a "sentencing factor" which comes into play only after the defendant's guilt has been determined beyond a reasonable doubt. ${ }^{83}$ The Court acknowledged that "there are constitutional limits to the State's power in this regard," but explicitly declined to define those limits. ${ }^{84}$ Noting that sentencing courts have traditionally heard evidence without any prescribed burden of proof at all, ${ }^{85}$ the Court declared that the preponderance of the evidence standard at sentencing satisfies the requirements of due process ${ }^{86}$ In the words of Justice Thomas, "[McMillan] spawned a special sort of fact known as a sentencing enhancement."

In Almendarez-Torres $v$. United States ${ }^{88}$ the Court analyzed the due process implications of a federal statute's penalty provision that authorized a maximum prison term of twenty years for any deported alien convicted of illegal reentry into the United States if the initial deportation were subsequent to an aggravated felony conviction. ${ }^{89}$ The offense of illegal reentry, absent the prior conviction, carried a maximum penalty of two years imprisoument. ${ }^{90}$ Relying on McMillan, the Court concluded that the penalty clause was a sentencing factor and did not set out a separate offense with a separate penalty. ${ }^{91}$ Furthermore, the Court found that it is normally Congress' role to decide which factors are elements and which are sentencing factors. ${ }^{92}$ Therefore, it was constitutionally permissible for a judge to determine the fact of prior conviction by a preponderance of the evidence. $^{93}$

\section{Jones v. United States}

Thus in conjunction with McMillan, Almendarez-Torres seemed to significantly limit the scope of due process protection at sentencing.

83. McMillan, 477 U.S. at 85,86 . Patterson, the Court reasoned, teaches that the judiciary should defer to legislative drafting and "hesitate to conclude that due process bars the State from pursuing its chosen course in the area of defining crimes and prescribing penalties." $I d$. at 86.

84. Id. at 86. The Court merely stated that it was "persuaded by several factors that Pennsylvania's Mandatory Minimum Sentencing Act does not exceed those limits." Id.

85. Id. at 91 (citing Williams v. New York, 377 U.S. 241 (1949)).

86. Id. at 92-93. Relying on Winship, Justice Stevens's dissent criticized the difference between "element" and "sentencing factor," arguing that due process requires the beyond a reasonable doubt standard for severely penalized conduet. Id. at 96 (Stevens, J., dissenting).

87. Apprendi v. New Jersey, 530 U.S. 466, 500 (2000) (Thomas, J., concurring).

88. 523 U.S. 224 (1998).

89. Id. at 226.

90. Id.

91. Id. at 228. Of course, if the penalty clause had set out a "separate offense," then the prior felony conviction would have been an "element" of that offense, subject to the reasonable doubt standard announced in In re Winship, 397 U.S. 358, 364 (1970). Patterson and McMillan left the reasonable doubt standard undisturbed for "elements" of a crime. See Patterson v. New York, 432 U.S. 197,210 (1977); McMillan, 477 U.S. at 85.

92. Almendarez-Torres, 523 U.S. at 228.

93. See id. at 247. 
However, the following year in Jones $v$. United States, the Court announced the "constitutional principle" that

under the Due Process Clause of the Fifth Amendment and the notice and jury trial guarantees of the Sixth Amendment, any fact (other than prior conviction) that increases the maximum penalty for a crime must be charged in the indictment, submitted to a jury, and proven beyond a reasonable doubt. ${ }^{94}$

This "principle" became the holding in Apprendi. ${ }^{95}$

The defendant in Jones was convicted of aiding and abetting a carjacking. The federal statute at issue read as follows:

Whoever, possessing a firearm ... takes a motor vehicle that has been transported, shipped or received in interstate or foreign commerce from the person in the presence of another by force or violence or by intimidation, or attempts to do so, shall-

(1) be fined under this title or imprisoned not more than 15 years, or both,

(2) if serious bodily injury ... results, be fined under this title or imprisoned not more than 25 years, or both, and

(3) if death results, be fined under this title or imprisoned for any number of years up to life or both. ${ }^{96}$

The indictment made no reference to the numbered subsections and did not charge any of the facts listed in the latter subsections. The jury instructions used at trial defined the elements using only the first paragraph, with no reference to serious bodily injury. ${ }^{97}$ The presentence report, however, alleged that one of the victims had suffered serious bodily injury and recommended that the defendant be sentenced to twenty-five years for the carjacking. Over the defendant's objections that serious bodily injury was an element of the offense, and thus must be proven to the jury beyond a reasonable doubt, the district court found that the allegation was supported by a preponderance of the evidence and imposed a twenty-five year sentence on the carjacking count. ${ }^{98}$

The Supreme Court reversed the defendant's sentence, holding that the statute should be read as setting out three distinct offenses, rather than "a single crime with a choice of three maximum penalties, two of them dependant on sentencing factors exempt from the requirements of charge and jury verdict." $" 99$ It explained that interpreting the subsections as

94. 526 U.S. 227,243 n.6 (1999).

95. See Apprendi, 530 U.S. at 476 .

96. Jones, 526 U.S. at 230 (citing 18 U.S.C $\$ 2119$ (1998)).

97. Id. at 230-31.

98. Id. at 231-32. In another case involving the same federal statute, the Ninth Circuit Court of Appeals similarly determined that the subsections set out sentencing factors, not definitions of separate crimes. See United States v. Oliver, 60 F. 3d 547 (9th Cir. 1995), rev'd sub nom. Jones v. United States, 526 U.S. 227 (1999).

99. Jones, 526 U.S. at 229. 
sentencing factors would expose the statute to constitutional doubt in light of the last quarter century of Supreme Court jurisprudence dealing with due process and the guarantee of a jury trial. ${ }^{100}$ Drawing on the cases discussed in the previous Part, the Court identified the principle that became the Apprendi rule: "any fact (other than prior conviction) that increases the maximum penalty for a crime inust be charged in an indictment, submitted to a jury, and proven beyond a reasonable doubt.".101 It further concluded that, "[b]ecause our prior cases suggest rather than establish this principle, our concern about the Government's reading of the statute rises only to the level of doubt, not certainty." 102 Nonetheless, the Court reasoned, the doctrine of constitutional doubt dictates that "where a statute is susceptible of two constructions, by one of which grave and doubtful constitutional questions arise and by the other of which such questions are avoided, our duty is to adopt the latter."103

Justice Kennedy wrote for the dissent, expressing alarm at the majority's suggestion that interpreting the statute as setting out one offense with sentencing factors rather than three separate offenses might render it vulnerable to a constitutional challenge. He opined that the majority opinion was "cause for much concern" because it did not just limit itself to the question of statutory interpretation but instead "raises the specter" of grave constitutional doubts which are unsupported by the Court's recent authority. ${ }^{104}$ Therefore, he contended, "the Court's sweeping constitutional discussion casts doubt on sentencing practices and assumptions" followed in the federal systeins and many states. ${ }^{105}$

100. Id. at 240. The Court then launched into an analysis of the legal background cases discussed, supra, in Part ll.A\&B. The Court explained that Mullaney v. Wilbur, 421 U.S. 684 (1975), limited the government's choice concerning the characterization of facts as elements or sentencing factors. Id. at $240-41$. This was necessary, the Court opined, in order to preserve the reasonable doubt standard as explained in In re Winship, 397 U.S. 358 (1970). Patterson v. New York, 432 U.S. 197 (1977), it contended, explicitly recognized a limitation on governmental authority to reallocate burdens of proof. Id. at 241. See infra Part III.C for a discussion of the Court's use of precedent to support the Apprendi holding.

101. Id. at 243 n.6.

102. Id.

103. Id. at 239 (quoting United States ex rel. Attorney Gen. v. Delaware \& Hudson Co., 213 U.S. 366,408 (1909)). The Court made clear that interpreting the statute as setting out one offense with varying sentencing factors (as the government urged) rather than as setting out separate offenses with separate penalties would put the statute in danger of being unconstitutional. Thus in accordance with the doctrine of constitutional doubt the Court chose the interpretation that would not leave the statute vulnerable to a constitutional challenge. See id. at 251.

104. Id. at 254 (Kennedy, J., dissenting). He contended that the Court's "precedents admit of no real doubt regarding the power of Congress to establish serious bodily injury and death as sentencing factors rather than offense elements, as we made clear in Almendarez-Torres." Id. The voting alignment in Jones is identical to Apprendi: Justices Souter, Stevens, Scalia, Thomas and Ginsburg constitute the majority; Justices Kennedy, Rehnquist, O'Connor and Breyer dissented.

105. Id. Not only were the Court's constitutional doubts not well founded in precedent, Justice Kennedy maintained, neither did it make out a principled argument for its departure from stare decisis. Id. at 268-70. 
Thus, although McMillan did not specify the limits of legislative power to transmute elements into sentencing factors, Jones appeared to identify one such limit: facts (other than recidivism) which increase the maximum penalty for a crime must be proven to a jury beyond a reasonable doubt. While the holding itself merely reinterpreted the statute to conform to this constitutional principle ${ }^{106}$ (and ascribed legislative intent to this interpretation), ${ }^{107}$ Apprendi's codification of the same principle as a concrete rule demonstrates the rule's function as a check on legislative discretion to define elements and sentencing factors. ${ }^{108}$ Although it didn't contradict the holdings of Williams and Almendarez-Torres, Jones signaled a departure from the trend of expanding the fact-finding role of judges at sentencing, while leaving undisturbed the lower standard of proof attached to sentencing proceedings.

\section{III \\ AN INCREASED Guidelines RaNGe Is AN INCREASE IN THE “MAXIMUM SENTENCE"}

Because Apprendi dealt with a state statute and did not specify how its holding affects the United States Sentencing Guidelines, its impact on federal sentencing practices must be inferred. Crucial to determiming its effect on the Relevant Conduct Provision of the United States Sentencing Guidelines is the question of whether an increase in the guidelines range for an offense is considered an increase in the "maximum sentence." If not, then the Apprendi rule is inapplicable since it only applies to increases in the maximum sentence for a crime. However, the language and reasoning of Jones and Apprendi and their interpretation of precedent, particularly the Almendarez-Torres decision, indicate that an increase in the guidelines range constitutes an increase in the maximum sentence. Examining a representative federal statute and its corresponding sentencing guideline shows how the Apprendi rule applies.

\section{A. The Federal Drug Possession Statute and Corresponding Sentencing Guideline}

In Apprendi, the United States amicus curiae brief supporting respondent New Jersey was filed to oppose the threat to federal sentencing practices, which allow for judicial, rather than jury, fact-finding at

106. That is, rather than striking down the statute, the Court interpreted it as establishing three separate offenses with distinct elements, each of which must be charged in an indictment and proven to a jury beyond a reasonable doubt. See id. at $25 \mathrm{l}$.

107. See id. at 236.

108. The New Jersey Hate Crime Statute is drafted to set out sentencing factors, rather than a separate crime with its own elements. See Apprendi v. New Jersey, 530 U.S. 466, 467 (2000); see also supra note 31. 
sentencing. ${ }^{109}$ The government pointed to 21 U.S.C. $\$ 841$ (b), the federal drug possession statute, as an example of the type of federal criminal law that "authorizes" sentence enhancements on the basis of judicial factfinding. ${ }^{110}$ Justice Breyer's dissent used the same statute as an example, declaring that "the majority's rule creates serious uncertainty about the constitutionality of such statutes and about the constitutionality of the confineinent of those punished under them." corresponding sentencing guideline make a useful representative example for exploring the impact of Apprendi on the range-enhancing provisions of the United States Sentencing Guidelines.

The statute reads in pertinent part as follows:

(a) Unlawful Acts. Except as authorized by this title, it shall be unlawful for any person knowingly and intentionally-

(1) to manufacture, distribute or dispense, or possess with intent to manufacture, distribute or dispense, a controlled substance; or

(2) to create, distribute or dispense, or possess with intent to distribute or dispense, a counterfeit substance.

(b) Penalties. Except as otherwise provided ... any person who violates subsection (a) of this section shall be sentenced as follows:

(1) (A) In the case of a violation of subsection (a) of this section involving-

(i) 1 kilogram or more ...;

(ii) 5 kilograms or more...;

....

... [s]uch person shall be sentenced to a tern of imprisonment which may not be less than 10 years .... ${ }^{112}$

The remainder of the lengthy statute similarly sets out correspondimg sentences depending on drug types and quantities. ${ }^{13}$

However, despite the government's and Justice Breyer's contention, the statute itself does not specify whether the facts supporting the increased sentences are to be found by a judge at sentencing or a jury at trial. Significantly, the statute provides that the penalties apply to any person who

109. Brief for the United States as Amicus Curiae at 1, Apprendi v. New Jersey, 530 U.S. 466 (2000) (No. 99-478). The petitioner argued that the sentencing guideline ranges do not set out "maximum sentences" for the offense; instead "the maximum possible sentence is always restricted to that of the underlying statutory offense of conviction." Petitioner's Brief at 36, Apprendi (No. 99-478).

110. Brief for the United States as Amicus Curiae at 1, Apprendi (No. 99-478). The government asserted that "[b]ecause various federal criminal laws authorize the imposition of enhanced sentences on the basis of facts found by the court at sentencing, see, e.g., 21 U.S.C. 841(b) (drug type and quantity), the United States has a strong interest in the outcome of this case." Id.

111. Apprendi, 530 U.S. at 565 (Breyer, J., dissenting).

112. 21 U.S.C. $\$ 841$ (a)-(b) (2000).

113. Id. In fact, the structure of the statute is similar to the one determined by the Court in Jones to set out separate offenses with separate punishments. Compare id., with 18 U.S.C $\$ 2119$ (1998). 
"violates," not "who is convicted" under, the first section. The numbered subsections specify it is a "violation" of the first subsection that involves the drug quantity. Because the statute uses the term "violates" throughout, both in the definition of the offense and in the sentencing subsections, the plain language of the statute itself lends more support to the interpretation that the drug types and quantities attached to varying penalties are part of the offense of conviction.

The corresponding Federal Sentencing Guideline reads in part as follows:

(a) Base Offense Level (Apply the Greatest)

(1) 43 if the defendant is convicted under 21 U.S.C. $\$ 841$ (b) ... and the offense of conviction establishes that death or serious bodily injury resulted ... ;

(2) 38 if the defendant is convicted under 21 U.S.C. $\S 841$ (b) ... and the offense of conviction establishes that ...;

(b) Specific Offense Characteristics

(1) If a dangerous weapon (including a firearm) was possessed ... increase by 2 levels

(2) If the defendant unlawfully imported or exported a controlled substance . . . increase by 2 levels. ${ }^{114}$

The remainder of the guideline sets out specific offense characteristics in numbered subsections, each specifying the requisite increase in the guidelines range corresponding to the relevant facts. ${ }^{115}$ This structure is used throughout the federal sentencing guidelines. ${ }^{116}$

Note that the Base Offense Level Provision rests on facts established by the offense of conviction. The guideline itself does not specify how the specific offense characteristics are to be determined. Rather, it is the Relevant Conduct Provision which instructs that the range-enhancing offense characteristics are to be determined by considering all acts that were part of the "same course of conduct or common scheme or plan as the offense of conviction." 117 Therefore, if federal criminal sentencing under

114. U.S. Sentencing Guidelines Manual §2D1.1(a)-(b) (2000). This section is entitled "Unlawful Manufacturing, Importing, Exporting, or Trafficking (Including Possession with lntcnt to Commit Thesc Offenses); Attempt or Conspiracy." The numbers forty-three, thirty-eight, etc. refer to the offense level. The offense level in tandem with the Criminal History Category determines the guidelines range for an offense. For example, forty-three is life imprisonment regardless of previous criminal history. Thirty-eight is 235-293 months for Criminal History Category I, 262-327 for Category Il, 292-365 for Category III, 324-405 for Category IV, and 360-life for Categories V and VI. U.S. Sentencing Guidelines Manual, sentencing tbl. (2000); see supra note 14.

115. U.S. Sentencing Guidelines Manual § 2DI.1(a)-(b) (2000).

116. See generally U.S. Sentencing Guidelines Manual (2000).

117. U.S. Sentencing Guidelines Manual $\$ 1 B 1.3(a)(2)(2000)$. The application notes to the Relevant Conduct Provision explain that:

[t]he principles and limits of sentencing accountability under this guideline are not always the same as the principles and limits of criminal liability .... [T] he focus is on the specific acts and omissions for which the defendant is to be held accountable in determining the applicable 
the drug possession statute is affected by the Apprendi rule, as Justice Breyer and the government's brief contended, then it must be because Apprendi applies to the Relevant Conduct Provision of the sentencing guidelines.

\section{B. The Language and Reasoning of Apprendi and Jones}

The majority in Apprendi provided no explicit guidance to lower courts about who is ultimately responsible for making fact-finding decisions increasing the guidelines range. Although the dissents in both Apprendi and Jones expressed concern over the effects of the rulings on the federal determinate-sentencing schemes, suggesting that they understood an increase in the "Inaximum penalty" to refer to an increase in the guidelines range, the majority opinions themselves did not directly address this issue. In Apprendi, the only mention of the topic was in a somewhat cryptic footnote at the end of the opinion. The Court remarked that it was "unnecessary to consider whether (and, if so, how) the rule regarding elements applies to the Sentencing Guidelines, given the unique status that they have under Mistretta $v$. United States." 118 However, the footnote continued, "[b]ut it may be that this special status is irrelevant, because the Guidelines "have the force and effect of laws."'119 Thus the Court seems to suggest that because the guidelines function like laws they should be treated like any other law so that the majority ruling applies to them as well. Yet this is by no means conclusive, lending support to Justice $O$ 'Connor's allegation in the dissent that the opimion provides insufficient guidance for lower courts. ${ }^{120}$

Jones provides more guidance concerning the rule's effect on the federal sentencing system. ${ }^{121}$ Also relying on a footnote at the end of the

guideline range, rather than on whether the defendant is criminally liable for an offense as a principal, accomplice, or conspirator.

U.S. Sentencing Guidelines Manual $\$ 1 B 1.3(a)(2)$, cmt. n.1 (2000). Note that the commentary specifically provides that conduct for which the defendant is not criminally liable (i.e. for which s/he has not been tried and convicted) may be used in determining the guidelines range.

118. Apprendi v. New Jersey, 530 U.S. 466, 523 n.11 (2000) (citing Mistretta v. United States, 488 U.S. 361, 413 (1989) (Scalia, J., dissenting)). Mistretta held that Congress' establishment of the United States Sentencing Commission was not an unconstitutional delegation of legislative power and did not violate separation of powers because the commission is not a court and does not exercise judicial power. Mistretta, 488 U.S. at 412 . The nature of sentencing commission presumably endows the guidelines with the "special status" to which the majority refers.

119. Apprendi, 530 U.S. at 523 n.11.

120. See Apprendi, 530 U.S. at 551-52 (O'Connor, J., dissenting).

121. The language the Court used in Jones is relevant for determining the effect of the Apprendi rule, even though of course Apprendi deait with a state statute whereas Jones interpreted a federal statute. Both cases concerned themselves with constitutional due process protections which are equally applicable to state or federal sentencing practices. The voting line-up in the two cases was identical (Justices Souter, Stevens, Scalia, Thomas and Ginsburg were in the majority while Justices Kennedy, Rehnquist, O'Connor, and Breyer dissented in both cases); furthermore, the Court noted in Apprendi that its ruling "was foreshadowed by our opmion in Jones $v$. United States construing a federal statute," 
opinion, the majority addressed the dissent's concern that the rule would "unsettle" administratively-established guidelines governing sentencing decisions: "[l]f the constitutional concern we have expressed should lead to a rule requiring jury determination of facts that raise a sentencing ceiling, the rule would in no way constrain legislative authority to identify the facts relevant to punishment or to establish fixed penalties."122 The rule, according to the majority, would apply only to "the procedures by which the facts that raise the possible penalty are to be found, that is what notice must be given, who must find the facts, and what burden must be satisfied to demonstrate them." 123 This reference to "facts which raise the possible penalty" in the context of a discussion of administrative sentencing guidelines supports the argument that the Apprendi rule, if read consistently with Jones, requires jury determination of facts that raise the applicable guidelines range. ${ }^{124}$

Yet the reasoning of the opinions themselves is what suggests most strongly that an increase in the guidelines range would constitute an increase in the "maximum penalty," and thus be subject to the procedural safeguards set out in Apprendi. The Court invalidated the New Jersey legislative scheme in Apprendi because it permitted a sentencing judge to determine facts which, if proven, exposed the criminal defendant "to a penalty exceeding the maximum he would receive if punished according to the facts refiected in the jury verdict alone." 125 The Apprendi Court agreed with Justice Stevens's analysis in Jones: "[i]t is unconstitutional for a legislature to remove from the jury the assessment of facts that increase the prescribed range of penalties to which a criminal defendant is exposed. It is equally clear that such facts must be established by proof beyond a reasonable doubt." 126

Apprendi, 530 U.S. at 476 , thus indicating that the two cases should be read in tandem. Although the holdings of the two cases are different, their rhetoric and reasoning, which are the subjects of this Note, are similar.

122. Jones v. United States, 526 U.S. 227, 252 n.ll (1999). That rule became the holding in Apprendi.

123. Id.

124. Remember that Apprendi specifically states that it is identifying as a constitutional rule the principle announced in Jones. Apprendi, 530 U.S. at 476. This suggests that Apprendi must be read consistently with Jones.

125. Id. at 482-83. The Court's repeated emphasis on "facts" which expose the defendant to greater punishments, as opposed to legislatively-designated "sentencing factors," signals a judicial hostility to permitting definitions to determine the character of a factual inquiry. The Court remarked disapprovingly that the modcrn distinction between "sentencing factors" and "elements" of a crime was unknown at the time of the Framers. Instead, "criminal proceedings were submitted to a jury after being initiated by an indictment containing 'all the facts and circumstances which constitute the offense." Id. at 478 .

126. Id. at 490 (citing Jones v. United States, 526 U.S. 227, 252-53 (1999) (Stevens, J., concurring)). 
Technically, it would be possible to read the latter holding in isolation and conclude that the "prescribed range of penalties" did not apply to the penalty range set by the sentencing guidelines after judicial factfinding, but rather to the outer limits for the general offense authorized by the underlying statute. For instance, given this reading, the "prescribed range of penalties" for "possession" of a controlled substance under 21 U.S.C. $\S 841$ could be anywhere from no jail time to life imprisonment. ${ }^{127}$ Apprendi's prohibition against increasing the penalty beyond the "prescribed range" without factfinding by a jury beyond a reasonable doubt would merely prohibit the judicial imposition of the death sentence.

However, it is impossible to reconcile this position with the Court's explicit statement that it invalidated the New Jersey statute because it exposed the defendant to a risk of greater punishment than he would receive "if punished according to the facts reflected in the jury verdict alone." we know from the example of Cheryl Putra discussed in the Introduction, under the traditional application of the federal drug possession statute, a jury may find a defendant guilty of possession of only one ounce of cocaine, yet the defendant can still be sentenced under the guidelines range for a greater amount upon subsequent judicial factfinding. ${ }^{129}$ Thus it defies logic to argue that exempting upward extensions of the guidelines range from the prohibition against judicially-increasing "maximum penalties" is consistent with "punishing the defendant according to the facts reflected in the jury verdict alone." 130

The reasoning im Jones also supports the conclusion that the term "maximum penalty" applies to a sentencing guidelines range. In discussing the origins of the "constitutional doubt" identified in the opinion, the Court argued that McMillan raised but never addressed due process concerns regarding "factfinding that raises a sentencing range."131 The question posed by that case, the Court said, was "may judicial factfinding by a preponderance support the application of a provision that increases the potential severity of the penalty for a variant of a given crime?"132 Significantly, the Court equated here an increase in the "sentencing range" with an increase in the punishment for a "variant" of a given crime. Again, the federal drug possession statute demonstrates how this principle applies. ${ }^{133}$

127. 21 U.S.C. $\$ 841(2000)$.

128. Apprendi, 530 U.S. at 483.

129. See United States v. Putra, 78 F.3d 1386, 1387 (9th Cir. 1996), rev'd per curiam sub nom. United States v. Watts, 519 U.S. 148 (1997). See also supra notes 1-5 and accompanying text.

130. The Court also emphasizes that the "relevant inquiry" in assessing the constitutionality of a sentencing provision was "not one of form, but of effect-does the required finding expose the defendant to greater punishment than that authorized by the jury's guilty verdict?" Apprendi, 530 U.S. at 494.

131. Jones v. United States, 526 U.S. 227, 242 (1999).

132. Id.

133. See 21 U.S.C. $\$ 841$ (2000); U.S. Sentencing Guidelines ManuaI § 2 D1.1 (2000). 
The increases for "variants" of possession must be the increases in the sentencing guidelines ranges based on judicial findings of drug type and quantity. If the "sentencing range" were merely the upper and lower limits of the statute as a whole, then there would be no "variants" of the crime, or most other federal crimes, for the purpose of the principle announced in Jones. Furthermore, if a federal statute in its entirety defined the "sentencing range," then the federal statute at issue in Jones itself would also constitute only one "sentencing range," a position clearly rejected by the Court's ruling.

\section{The (Re)Interpretation of Precedent}

The manner in which the Court marshals authority for Apprendi and Jones also indicates that the Apprendi rule applies to the federal sentencing guidelines.

In Apprendi the Court traced the history of the Supreme Court's jurisprudence regarding both procedural safeguards for criminal defendants and the role of judicial factfinding at sentencing, emphasizing the importance of the reasonable doubt standard as codified in Winship (and expanded in Mullaney) for reducing the risk of erroneous factual determinations. ${ }^{134}$ The "primary lesson" of Mullaney, the Court opined, is that Winship's due process protection and jury guarantee extend not only to the determination of the defendant's guilt or innocence, but also to the "length of his sentence." ${ }^{135}$ Mullaney teaches, the Court concluded, that criminal law "is concerned not only with guilt or innocence in the abstract, but also with the degree of criminal culpability assessed."136 This explicit linking of due process and jury trial guarantees with factual determinations concerning the degree of a defendant's culpability strongly suggests that Apprendi's due process concerns would extend to the type of factual determinations used to set the penalty range under the federal sentencing guidelines. Otherwise, the jury's verdict would merely answer the question of guilt or innocence, a limitation explicitly rejected by the Court. ${ }^{137}$

Significantly, the Court neglected to discuss the decision in Patterson v. New York, which contradicts Apprendi's reading of Mullaney. As the Apprendi dissent pointed out, the Patterson court held that Mullaney should not be read so broadly as to prohibit a state from allowing the severity of punishment "to depend on the presence or absence of an identified fact without assuming the burden of proving the presence or absence of that

134. Apprendi, 530 U.S. at 484 (citing In re Winship, 397 U.S. 358, 363 (1970)).

135. Id. (quoting Almendarez-Torres v. United States, 523 U.S. 224, 251 (1998)).

136. Id. at 485 (quoting Mullaney v. Wilbur, 421 U.S. 684, 697-98 (1975)).

137. The Court explained that "[s]ince Winship, we have made clear beyond peradventure that Winship's due process and associated jury protections extend, to some degree, to determinations that go not to a defendant's guilt or innocence, but simply to the length of his sentence." Id. at 484 (citation omitted). 
fact... beyond a reasonable doubt." ${ }^{\prime 138}$ Thus the dissent correctly noted that Patterson "plainly refutes the Court's expansive reading of Mullaney." 139 By readopting the expansive principle in the form initially stated in Mullaney, the Court appeared to be implicitly overruling Patterson. ${ }^{140}$ The broader Mullaney holding, in turn, clears the way for application of the jury trial and due process guarantees to the Relevant Conduct Provision of the sentencing guidelines.

The Court's reading of McMillan is particularly pertinent to the application of Apprendi to the Relevant Conduct Provision. The Apprendi Court acknowledged without elaboration that McMillan extends the Court's blessing to judicially-determined "sentencing factors." majority contended that McMillan stands for the proposition that a state scheme which prevents a jury from determining facts that expose defendants to greater punishment may raise constitutional concerns. ${ }^{142}$ They further pointed out that McMillan permitted judicial findings of sentencing factors only for setting a mandatory minimum that fell within the sentencing ranges already available to the court without the additional finding. ${ }^{143}$

The dissent took issue with the majority's reliance on McMillan's identification of "constitutional concerns," noting that McMillan explicitly reaffirmed the Patterson holding that severity of punishment need not be linked to facts proven beyond a reasonable doubt, and that the legislature's definitions of elements are usually dispositive. ${ }^{144}$ The majority replied to the dissent's allegation that the Court had implicitly overruled McMillan by stating that although McMillan still stands, "[w]e limit its holding to cases that do not involve the imposition of a sentence more severe than the statutory maximum for the offense established by the jury's verdict."145

138. Id. at 531 (O'Connor, J., dissenting) (quoting Patterson v. New York, 432 U.S. 197, 214-15 (1977)).

139. Id.

140. As Justice Brennan noted, Patterson bore little resemblance to the basic rationale underlying Mullaney. See Patterson, 432 U.S. at 223 (Brennan, J., dissenting). The Apprendi dissent contended that the majority had implicitly overruled Patterson by adopting Mullaney's reading of Winship. Apprendi, 530 U.S. at 544. Jones conceded that Patterson left States free to chose which elements to define as crimes. However, the Court asserted that this permission came with the "stated recognition of some limit upon the state authority to reallocate the traditional burden of proof." Jones v. United States, 526 U.S. 227, 241 (1999). It concluded that Patterson was thus susceptible to an interpretation that States lacked the discretion to omit "traditional" elements from the definitions of crimes. Id. at 241-42.

141. Apprendi, 530 U.S. at 485-86.

142. Id. at 486 (citing McMillan v. Pennsylvania, 477 U.S. 79, 88 (1986)).

143. Id. (citing McMillan, 477 U.S. at 87-88). Despite its emphasis on the importance of the reasonable doubt standard for due process, the majority does not address McMillan's holding that the preponderance of the evidence standard satisfies due process at sentencing. See McMillan, 477 U.S. at 92-93.

144. Apprendi, 530 U.S. at 533-34 (O'Connor,. J., dissenting).

145. Id. at 487 n.13. The majority adds that "[c]onscious of the likelihood that legislative decisions may have been made in reliance on McMillan, we reserve for another day the question whether stare 
Therefore, because McMillan-authorized "sentencing factors" can now only determine a sentence within the range available without an additional finding, it is likely that using the Relevant Conduct Provision to extend a guidelines range violates the Apprendi rule. ${ }^{146}$

\section{The "Special Case" of Almendarez-Torres}

Comparing the Apprendi Court's interpretation of Almendarez-Torres with the Almendarez-Torres ${ }^{147}$ decision itself provides the most insight into how the Apprendi rule will affect the sentencing guidelines. The Court noted that Almendarez-Torres permits a judicial finding of a defendant's prior felony convictions to raise the term of imprisonment higher than that attached to the crime charged in the indictment. ${ }^{148}$ This construction is significant because it defines the "maximum penalty" not as the range set out in the statute in its entirety, but only that attached to the offense of conviction. ${ }^{149}$

The Court deemed Almendarez-Torres a "narrow exception" to the general rule announced in Apprendi. ${ }^{150}$ The procedural safeguards attached to any "fact" of prior conviction, it argued, mitigate "the due process and Sixth Amendment concerns otherwise implicated in allowing a judge to determine a 'fact' increasing punishment beyond the maximum statutory range." 151 Since due process and Sixth Amendment requirements were already followed in the original conviction, the Court had no problem with judicial determination of that particular "fact." Likewise, in Jones, the Court argued that the Almendarez-Torres majority's "repeated emphasis on the distinctive significance of recidivism leaves no question that the Court regarded that fact as potentially distinguishable for constitutional purposes from other facts that might extend the range of possible sentences." ${ }^{152}$ The

decisis considerations preclude reconsideration of its narrower holding." Id. The Court's language hints that McMillan is disfavored, although not overruled.

146. The Court's emphasis in both Jones and Apprendi on the fact that the defendant in McMillan was not exposed to greater punishment through the finding of the sentencing factor than he would have been without the additional finding indicates that the Court's definition of "statutory maximum" is linked to the actual exposure to punishment authorized by the jury's finding of fact. See Apprendi, 530 U.S. at 486-87; Jones v. United States, 526 U.S. 227, 242 (1999).

147. See supra notes $88-93$ and accompanying text.

148. Apprendi, 530 U.S. at 488.

149. The statute's structure is similar to the federal statutes discussed previously. 1t has a general offense paragraph which specifies a term of no more than two years imprisonment for illegal reentry. This is the "maximum penalty." There is a second section setting out numbered subsections with penalties attached, including an enhanced penalty if the defendant had been deported subsequent to a prior conviction. See 8 U.S.C. $\$ 1326$ (2000). Almendarez-Torres was sentenced under the second section, although he was only charged under the first section. Almendarez-Torres v. United States, 523 U.S. 224, 226 (1998).

150. Apprendi, 530 U.S. at 490.

151. Id. at 488 .

152. Jones, 526 U.S. at 249. Again note that the "range of possible sentences" refers to the range attached to the specific offense of conviction, not the statute as a whole. 
emphasis on the "distinctive significance" of Almendarez-Torres and its confinement solely to the fact of recidivism reinforces Apprendi's emphasis on the procedural safeguards that must accompany a factual finding increasing the penalty range. If recidivism is an exception because the prior conviction itself was a fact found by a jury beyond a reasonable doubt, as the Court indicated, then it follows that any other facts not accompanied by the same procedural safeguard would not be permitted to raise the penalty range in the same manner as did recidivism in Almendarez-Torres.

Yet the Apprendi Court's understanding of Almendarez-Torres seems to differ significantly from the reasoning of the case itself. ${ }^{153}$ The majority in Almendarez-Torres relied extensively on McMillan's emphasis on deference to the legislature's definition of sentencing factors. ${ }^{154}$ While acknowledging that Winship mandates proof beyond a reasonable doubt for every fact necessary to constitute a charged crime, the Almendarez-Torres Court argued that it provides no guidance for distinguishing sentencing factors from elements. ${ }^{155}$ The majority conceded that a literal reading of Mullaney suggests that sentences cannot be increased for any factor not set fortli in an imdictment and proven to a jury beyond a reasonable doubt. ${ }^{156}$ However, they pointed to Patterson which suggests "the exact opposite," that "the Constitution requires scarcely any sentencing factors to be treated in that way." 157 The Almendarez-Torres majority further contended that the statute in question is similar to the one validated in McMillan but for the fact that it alters the maxinum penalty for the crime. ${ }^{158}$ However, they concluded that this difference does not change the "constitutional outcome" because it does not create a greater risk of unfairness to the defendant than does an increase in the mandatory minimum. ${ }^{159}$

Nowhere does the Almendarez-Torres majority suggest that recidivism is distinguishable because of the procedural safeguards attached to a prior conviction. By emphasizing deference to the legislature on designations of sentencing factors and asserting that an increase in the statutory maximum does not raise constitutional concerns, the decision strongly supports the conclusion that facts which increase a guidelines range need not be found by a jury beyond a reasonable doubt. ${ }^{160}$ The statute at issue was

153. Justice Stevens, who wrote for the majority in Apprendi, dissented in Almendarez-Torres. Justice Breyer authored the majority opinion in Almendarez-Torres and dissented in Apprendi.

154. See Almendarez-Torres v. United States, 523 U.S. 224, 228 (citing McMillan, 477 U.S. at 8491).

155. Id. at $239-40$.

156. Id. at 240 .

157. Id. at 241 .

158. Id. at 243 .

159. Id. at $244-45$ (citing McMillan, 477 U.S. at 95 (Stevens, J., dissenting)).

160. The New Jersey Supreme Court relied extensively on Almendarez-Torres, declaring that its rationale should apply in Apprendi. See State v. Apprendi, 731 A.2d 485, 493 (N.J. 1999), rev'd, 530 U.S. 466 (2000). 
similar in structure to 21 U.S.C. $\$ 841$, the federal drug possession statute. ${ }^{161}$ Both contain a general offense definition and subsequent penalty provisions attached to various aggravating factors. ${ }^{162}$ Also, the corresponding sentencing guidelines possess the same structure. Both U.S.S.G. $\S 2$ L2.2, the guideline used in Almendarez-Torres, and U.S.S.G. $§ 2 D 1.1$, the guideline corresponding to 21 U.S.C. $\S 841$, contain provisions laying out the base offense level and a list of special offense characteristics. ${ }^{163}$ Thus, there is nothing to distinguish Apprendi and Almendarez-Torres based on the text and structure of the statutes and guidelines; the rule for one should be the rule for the other. Crucially, the majority in AlmendarezTorres described the sentence enhancement based on the sentencing guideline as an increase in the "maximum sentence." 164 Thus the rule after Almendarez-Torres clearly seemed to be that an increase in the guidelines range based on judicial factfinding is an increase in the statutory maximum, and is constitutionally permissible.

Despite the findings in Almendarez-Torres, Apprendi confines Almendarez-Torres to a "narrow exception" for recidivism and implicitly overrules (or at least severely limits) the McMillan and Patterson decisions on which the case relies. Apprendi effectively rejects the reasoning put forth in Almendarez-Torres for permitting judicial factfinding by a preponderance of the evidence to support sentence guidelines penalty range enhancements. Nonetheless, the understanding that an increase in the applicable guideline range constitutes an increase in the "maximum penalty" is left intact.

\section{IV}

\section{Apprendi's Impact on Federal Sentencing Practices}

Tracing the logic of Apprendi and Jones suggests that Apprendi's rule, "any fact (other than prior conviction) that increases the maximum sentence for a crime must be charged in an indictment, submitted to a jury, and proven beyond a reasonable doubt," 165 applies to factual determinations that raise the guidelines range for an offense. However, this rule should not encroach on judicial factfinding at sentencing for determining the appropriate sentence within the guidelines range for the offense of conviction because these facts have been proven to a jury beyond a reasonable doubt. While Apprendi should invalidate the use of the Relevant Conduct Provision of the federal sentencing guidelines to increase the guidelines

161. See supra Part Ill.A.

162. Compare 8 U.S.C. $\$ 1326(2000)$ with 21 U.S.C. $\$ 841$ (2000).

163. Compare U.S. Sentencing Gumelines Manual $\S 2$ L2.2 (2000) with U.S. Sentencing Guidelines Manual $\$ 2 D 1.1$ (2000).

164. Almendarez-Torres, 523 U.S. at 227.

165. Apprendi, 530 U.S. at 476. 
range for an offense, most underlying federal statutes and the substantive guidelines themselves should remain undisturbed.

\section{A. Deference to the Legislature}

Although the dissents in both Apprendi and Jones suggest that these decisions reject deference to the legislature, respect for the legislature actually necessitates the invalidation of the Relevant Conduct Provision. The dissents lamented the disruption these decisions will cause to the federal sentencing system and urged deference to the legislature as the appropriate course of conduct. ${ }^{166}$ This critique implied that the constitutional principle announced in these cases encroaches on the traditional legislative terrain of determining crimes and punishments. ${ }^{167}$ Yet, as the footnote in Jones pointed out, the decisions only bear on the procedures by which facts that support penalties are to be found, leaving the legislature free to define crimes and establish the corresponding punishments. ${ }^{168}$ In fact, under the Apprendi decision, the federal statutes in Jones and the drug possession statute would still stand as written. ${ }^{169}$ Unlike the statute in Apprendi, these statutes do not make reference to the procedures or standard of proof needed to apply the relevant sentencing provisions. ${ }^{170}$ Apprendi only requires one change: the particular variant of the defendant's alleged crime must be included in the indictment and tried to the jury. The statutes as written by the legislature remain the same.

However, the dissent rightly noted that the decisions call into question the range-enhancing provisions of the federal sentencing guidelines. ${ }^{171}$ But the flaw in the dissent's reasoning was equating deference to the legislature with deference to the federal sentencing commission. Comparing the corresponding enabling legislation setting out the duties of the sentencing commission with the Relevant Conduct Provision of the sentencing guidelines reveals that the guidelines appear to exceed the scope of their enabling legislation. 28 U.S.C. $\$ 994(1)$ provides:

The Commission shall insure that the guidelines promulgated ... reflect-

(1) the appropriateness of imposing an incremental penalty for each offense in a case in which the defendant is convicted of-

(A) multiple offenses committed in the same course of conduct ...

166. See supra notes $51-58$ and accompanying text.

167. See Apprendi, 530 U.S. at 524 (O'Connor, J., dissenting); Jones, 526 U.S.at 254 (Kennedy, J., dissenting).

168. Jones, 526 U.S. at 252 n.11; See supra note 122 and accompanying text.

169. The statute in Almendarez-Torres would also stand, even if the case were not an exception to the rule. See 8 U.S.C. $\$ 1326(2000)$.

170. See 18 U.S.C $\$ 2119(1998) ; 21$ U.S.C. $\$ 841$ (2000).

171. See supra notes $57-58$ and accompanying text. 
(B) multiple offense committed at different times ... ${ }^{172}$

However, the Relevant Conduct Provision requires the sentencing court to consider "all acts and omissions ... that were part of the same course of conduct or common scheme or plan as the offense of conviction."173 The commentary following the provision specifies that "application of this provision does not require the defendant, in fact, to have been convicted on multiple counts," 174 contradicting its enabling legislation. The background section adds, "[c]onduct that is not formally charged or is not an element of the offense of conviction may enter into the determination of the applicable guideline sentencing range." 175 The commentary concludes that "relying on the entire range of conduct, regardless of the number of counts that are alleged or on which a conviction is obtained, appears to be the most reasonable approach to writing workable guidelines for these offenses."176

Note that Congress directs the sentencing commission to produce guidelines authorizing increased penalties for defendants convicted of multiple offenses in the same course of conduct. ${ }^{177}$ In essence, the enabling legislation describes sentence enhanceinents applied after the relevant facts have been found by a jury beyond a reasonable doubt, a procedure already coinpliant with the Apprendi rule. It is the sentencing commission that has translated the legislative directive of $\S 994(1)$ into the Relevant Conduct Provision for determining guidelines range. ${ }^{178}$ Because it permits an increase in the available inaximum penalty based on facts not tried to a jury and proven beyond a reasonable doubt, it clearly conflicts with the principle announced in Apprendi. Under this reading, limiting the Relevant Conduct Provision of the guidelines shows more deference to congressional intent than leaving it intact. In the words of Justice Stevens, "we should presume that Congress intended the new sentencing Guidelines that it authorized in 1984 to adhere to longstanding procedural requirements enshrined in our constitutional jurisprudence."179

172. 28 U.S.C. $\$ 994(1)(2000)$.

173. U.S. Sentencing Guidelines Manual § 1B1.3(a)(2) (2000) (Relevant Conduct Provision).

174. U.S. Sentencing Guidelines Manual $\S 1$ 1B1.3, emt. n.3 (2000).

175. U.S. Sentencing Guidelines Manual § 1B1.3, cmt. background (2000).

176. Id.

177. 28 U.S.C. $\$ 994(1)(2000)$.

178. "As one of the original sentencing commissioners, Justice Breyer is one of the architects of the federal sentencing guidelines, and master of this domain. On the Court he has become the 'sentencing expert' and chief apologist for the guidelines." National Association of Criminal Defense Lawyers, Inc., Column: Controlled Substances: Supreme Court Holds Drug Type, Quantity, Not Jury Issue, 22 Champion 30, 31 (1998) (suggesting that Justice Breyer should disqualify himself from cases addressing the validity of the federal sentencing guidelines).

179. United States v. Watts, 519 U.S. 148, 165 (1997) (per curiam) (Stevens, J., dissenting). 


\section{B. Applying the Decision}

O'Connor's dissent in Apprendi chided the majority for failing to clarify the precise contours of the constitutional principle underlying its decision. Thus she contended that judges are "left in a state of limbo" concerning whether they should continue to sentence defendants in accord with determinate-sentencing statutes and guidelines. ${ }^{180}$ However, she added that the Court appears to hold "that a defendant is entitled to have a jury decide, by proof beyond a reasonable doubt, every fact relevant to the determination of sentence under a determinate-sentencing scheme."181 Neither of these two contentions is strictly true. The decision does in fact suggest a template for how defendants should be sentenced under the guidelines, although it is not explicitly stated. And not every fact relevant to the determination of the sentence must be proven to a jury, just those facts that serve to increase the guidelines range.

Under Apprendi, sentencing courts are still free to consider evidence that would be inadmissible at trial. Relying on Williams v. New York, the Court declared that nothing in the history of procedural protections for defendants suggests that it is impermissible for judges to consider "various factors relating both to offense and offender" when imposing judgment within a prescribed statutory range. ${ }^{182}$ The Court added that "a sentence imposed by a federal district judge, if within statutory limits, is generally not subject to review." 183

This conclusion comports with the federal sentencing statute. 18 U.S.C. $\$ 3661$ provides that "no limitation shall be placed on the information concerning the background, character, and conduct of a person convicted of an offense which a court of the United States may receive and consider for the purpose of imposing the appropriate sentence." responding sentencing guideline should also withstand scrutiny under Apprendi so long as the court's discretion is confined at the outer limits of the guideline range. The relevant sentencing guideline provides that " $[\mathrm{i}] \mathrm{n}$ determining the sentence to impose within the guideline range, or whether departure from the guidelines is warranted, the court may consider, without limitation, any information concerning the background, character and conduct of the defendant, unless otherwise prohibited by law." 185 The limited McMillan holding also clearly permits courts to continue using judicial

180. 530 U.S. 466, 551 (2000) (O'Connor, J., dissenting).

181. Id. at 549 .

182. Id. at 481 .

183. Id. at $481-82$ (citing Williams v. New York, 337 U.S. 241, 246 (1949)).

184. 18 U.S.C. $\$ 3661$ (2000).

185. U.S. Sentencing Gumelines Manual $\S 1 \mathrm{~B} 1.4$ (2000) This section is entitled "Information to be Used in Imposing Sentence (Selecting a Point Within the Guideline Range or Departing from the Guidelines)." Of course, a downward eparture from the guidelines range remains constitutional under Apprendi. 
factfinding for imposing sentence within the guidelines range established for the offense of conviction. ${ }^{186}$ There is nothing to suggest that courts will be prohibited from continuing to consider acquitted and uncharged conduct at sentencing, provided the finding is only used to apply a sentence within the guidelines range corresponding to the facts reflected in the jury verdict. ${ }^{187}$ Therefore Apprendi's only affect on the federal sentencing system should be the limitation of the sentencing procedures set forth in the Relevant Conduct Provision. Evidence of "relevant conduct" could only be considered in determining what sentence to impose within a guidelines range (or in determining a downward departure from the guideline range). The guidelines themselves with their definitions and corresponding sentences should be unaffected.

The example of Cheryl Putra discussed in the Introduction shows how this limitation should operate. Because she was convicted only of aiding and abetting the distribution of one ounce of cocaine, and acquitted of aiding in the distribution of five ounces of cocaine, ${ }^{188}$ her maximum sentence under Apprendi should be determined by the guidelines range for the one ounce of cocaine, the convicted offense. Thus if she were convicted today in a United States district court she should receive a lower sentence than the twenty-seven months she was required to serve due to the application of the Relevant Conduct Provision and the sentencing court's finding that she had participated in distributing the five ounces for which she had been acquitted. ${ }^{189}$ Under the applicable sentencing guideline, her term of imprisonment for the one ounce of cocaine would be fifteen to twenty-one months. ${ }^{190}$ Twenty-one months would therefore be the maximum sentence the judge could apply consistent with Apprendi. However, in determining the sentence to apply within that range, the court would remain free to consider the conduct underlying the acquitted charges. Thus the court could still hear evidence and make the finding that she had participated in the distribution of the five ounces of cocaine, and utilize that finding when applying sentence within the guidelines range for the convicted charge.

\section{CONCLUSION}

When the Court held in Apprendi v. New Jersey that "any fact (other than prior conviction) that increases the maximum sentence for a crime

186. See supra notes $145-146$ and accompanying text.

187. United States v. Watts, 519 U.S. 148 (1997) (per curiam) (upholding the use of acquitted conduct at sentencing), and Witte v. United States, 515 U.S. 389 (1995) (upholding the use of uncharged conduct at sentencing), are thus still good law. However, they are significantly limited after Apprendi because the acquitted and uncharged conduct can now only be used to determine a sentence within the guidelines range corresponding to the facts reflected in the jury verdict.

188. See supra note 1 and accompanying text.

189. See supra notes 4-5 and accompanying text.

190. U.S. Sentencing Guidelines Manual § 2D1.1(c) (2000). 
must be charged in an indictment, submitted to a jury, and proven beyond a reasonable doubt,"191 it did not specifically address this holding's effect on the application of the United States Sentencing Guidelines. However, the Court's reasoning and interpretation of precedent in Apprendi indicates that the case should bar the use of the Relevant Conduct Provision of the sentencing guidelines to increase the guidelines range for an offense when the facts supporting that increase have not been charged $\mathrm{n} 1$ an indictment and proven to a jury. Central to this determination is whether an increase in the guidelines range is an increase in the "maximum sentence" for the purposes of the Apprendi rule. The manner in which the Court analyzed the use of "facts that increase the prescribed range of penalties to which a defendant is exposed," leaves little doubt that an increase in the guidelines range is an increase in the inaximum sentence and should therefore fall under the Apprendi rule. ${ }^{192}$ Further, the Court's reinterpretation of precedent, particularly its limitation of the previously almost unrestranied use of "sentencing factors,"193 strongly suggests that using the Relevant Conduct Provision to increase a guidelinies range absent a jury's determination of the relevant facts would be impermissible. Therefore, although the Relevant Conduct Provision remains in effect, its use of acquitted and uncharged conduct to increase a defendant's sentence should now be restricted to the guidelines range authorized by the facts proven to a jury.

191. 530 U.S. $466,476(2000)$.

192. See id. at 490 (citing Jones v. United States, 526 U.S. 277, 252-53 (1999)).

193. See supra text accompanying note 145 . 
